\title{
A review of Sciurus Group studies on the red squirrel (Sciurus vulgaris): presence, population density and colour phases in Lombardy (Italy)
}

\author{
Carlo M. Biancardi*, Claudio G. Gnoli
}

\begin{abstract}
During the nineties of the last Century, under the inspiration of Luigi Cagnolaro, it had been founded a "Sciurus group", within the Research Centres of the Società Italiana di Scienze Naturali. Aim of the group was to start a campaign of researches on red squirrel populations in Lombardy, Italy promoting field master thesis on various topics: colour phases and indirect estimations of population densities. The researches were carried out during 10 years in 5 study areas. An investigation and census with questionnaires were started in parallel, with the collaboration of Forest Guards (CFS), Ecological Guards (GEV) and students of biological and natural sciences. The results were published in Italian or exposed in national and international congresses. This review has the purpose to show and critically discuss the overall results, and make them available to a broader audience. The dark colour phase, in the red squirrel, resulted associated to elevation and conifer woodlands, according to the thermoregulation theory, which consider the dark fur thicker and more suitable in cold environments. Squirrel population densities are subject to periodical fluctuations, in conifer woodlands, due to cones availability. Cone crops are subject to cycle with years of great production followed by years of lean. The recorded squirrel densities are middle-lows, but in line with data from similar environments.
\end{abstract} phases.

Key words: Red squirrel, Sciurus vulgaris, Nest density, Colour

Riassunto - Revisione del gruppo di lavoro "Sciurus group" sullo scoiattolo commune (Sciurus vulgaris): presenza, densità di popolazione e fasi di colore.

Negli anni '90, su impulso di Luigi Cagnolaro, è stato fondato un gruppo di lavoro "Sciurus group", all'interno dei Centri Studi della Società Italiana di Scienze Naturali. Scopo del gruppo era avviare ricerche sulle popolazioni di scoiattolo comune europeo in Lombardia, promuovendo anche tesi di laurea di campo su vari aspetti, dalle fasi di colore alla stima indiretta delle densità di popolazione. Le ricerche sono proseguite circa 10 anni, e hanno interessato 5 aree di studio. Parallelamente è stata avviata un'indagine e un censimento delle fasi di colore con questionari, dapprima presso le stazioni del Corpo Forestale dello Stato, e successivamente allargata a Guardie Ecologiche Volontarie e studenti di Scienze Biologiche o Naturali.

Centro Studi Fauna Vertebrata "Luigi Cagnolaro", Società Italiana di Scienze Naturali, C.so Venezia 55, 20121 Milano, Italia Email: csfv@scienzenaturali.org

* Corresponding author: carlo.biancardi@gmail.com

(C) 2016 Carlo M. Biancardi, Claudio G. Gnoli

Received: 21 March 2016.

Accepted for publication: 10 June 2016.
I risultati delle singole ricerche furono esposti a convegni e congressi o pubblicati in italiano. Questo lavoro di review ha lo scopo di riprendere e attualizzare i risultati complessivi, discuterli e renderli disponibili a un più vasto pubblico di ricercatori. La fase di colore scuro, nello scoiattolo, è risultata associata ad altitudini più elevate e a boschi con prevalenza di conifere, in accordo con la teoria della termoregolazione, che ritiene la pelliccia scura più folta e adatta ad ambienti freddi. Le popolazioni di scoiattolo comune sono soggette, specialmente in ambienti di conifere, a fluttuazioni delle densità di popolazione legate alla disponibilità di coni (e quindi semi), anch'essa soggetta a cicli con anni di produzione abbondante (pasciona) ed altri di magra. Le densità di popolazione rilevate sono medio-basse, ma in linea con le tipologie ambientali riscontrate.

Parole chiave: Scoiattolo, Sciurus vulgaris, Fluttuazione delle densità di popolazione, fasi di colore.

\section{INTRODUCTION}

The "Sciurus group" was a research unit, founded in the 1990s by Luigi Cagnolaro within the Study Centres of the Societá Italiana di Scienze Naturali, in collaboration with the Vertebrate Zoology section of the Museum of Natural History of Milan. The direction of the unit was assigned to the authors of this review, and based on voluntary work.

During the period 1991-2000 different studies, most of them master thesis, have been carried out under the co-tutorship of Luigi Cagnolaro and/or Carlo M. Biancardi, Claudio Gnoli and Laura Rinetti (Fig. 1). The results of these researches were presented to national and international congresses and symposia, and partially published, in Italian, on local scientific journals or bulletins. The purpose of this work is to take the highlights of the scientific production of that cycle, critically review the main results and make them available to a wider international audience.

The Eurasian red squirrel (Sciurus vulgaris L., 1758) populations of Italy and the UK are threatened by the introduction of the alien invasive grey squirrel (Sciurus carolinensis Gmelin, 1788) (e.g. Bertolino et al., 2014). At the beginning of the nineties, the "known" dangerous situations in Italy were in Piedmont and Genoa Nervi, while in Lombardy we feared the possible expansion of grey squirrels from the west.

One of the greatest concerns was about habitat fragmentation of lowland forests (e.g. Celada et al., 1994). 
However, the status of the red squirrel populations in the mountain part of the region was little known and, indeed, mountain conifer woodlands were considered safer for red squirrels, with respect to the alien grey squirrel invasion (e.g. Gurnell, 1987).

Following the huge work made by Wauters \& Dhondt $(1988 ; 1990)$, and the data from the (then) recent works of Grodzinski \& Sawicka-Kapusta (1970), Purroy \& Rey (1974), Grönwall (1982), we decided for low-budget but extended researches using indirect methods for estimating the squirrel density. In parallel, we started an investigation on the relative frequencies of different colour-phases, and their relationship with ecological parameters such as elevation and forest composition. The red squirrel is characterized by a coat colour polymorphism, which can be more or less evident across the different subspecies (Fig. 2). The S.v. fuscoater Altum, 1876, the subspecies present in Northern Italy, can show a high degree of polymorphism. The colour change can be gradual, as shown in Fig. 2, but usually it is possible to discriminate two (red and dark) or three (red, brown and black) colour phases (Andera, 1985; Wauters et al., 2004). When the census is made by visual survey, it is easier to discriminate only between red and dark colours, especially if the animals are spotted in woodlands, at distance, with the help of binoculars.
This review is based on data presented at the II Congresso Italiano di Teriologia (Biancardi, 1998a; 1998b; Biancardi et al., 1998), to the $6^{\text {th }}$ Squirrel Workshop (Biancardi \& Gnoli, 2001), and partially published in Biancardi (1999) and Aristarchi \& Canu (1999). The master theses produced during that cycle of researches were that of: Alessandra Speranza (1992), Claudio Aristarchi (1996), Franco Dell'Acqua (1998), Andrea Viganó (1998), Lorena Aquilini (2000).

\section{MATERIALS AND METHODS}

\section{Presence and colour phases}

The use of questionnaires to collect information about animal populations is a rapid and cost effective methodology, which today lies under the definition "citizen science" (Dickinson et al., 2010). The method has been used in the past century to investigate on presence and colour phases of red squirrel populations (Zawidzka, 1958; Andera, 1985), and nowadays replaced by more modern and effective methodology (e.g. Mori \& Menchetti, 2014). For the reasons exposed in introduction, we worked with two colour phases.

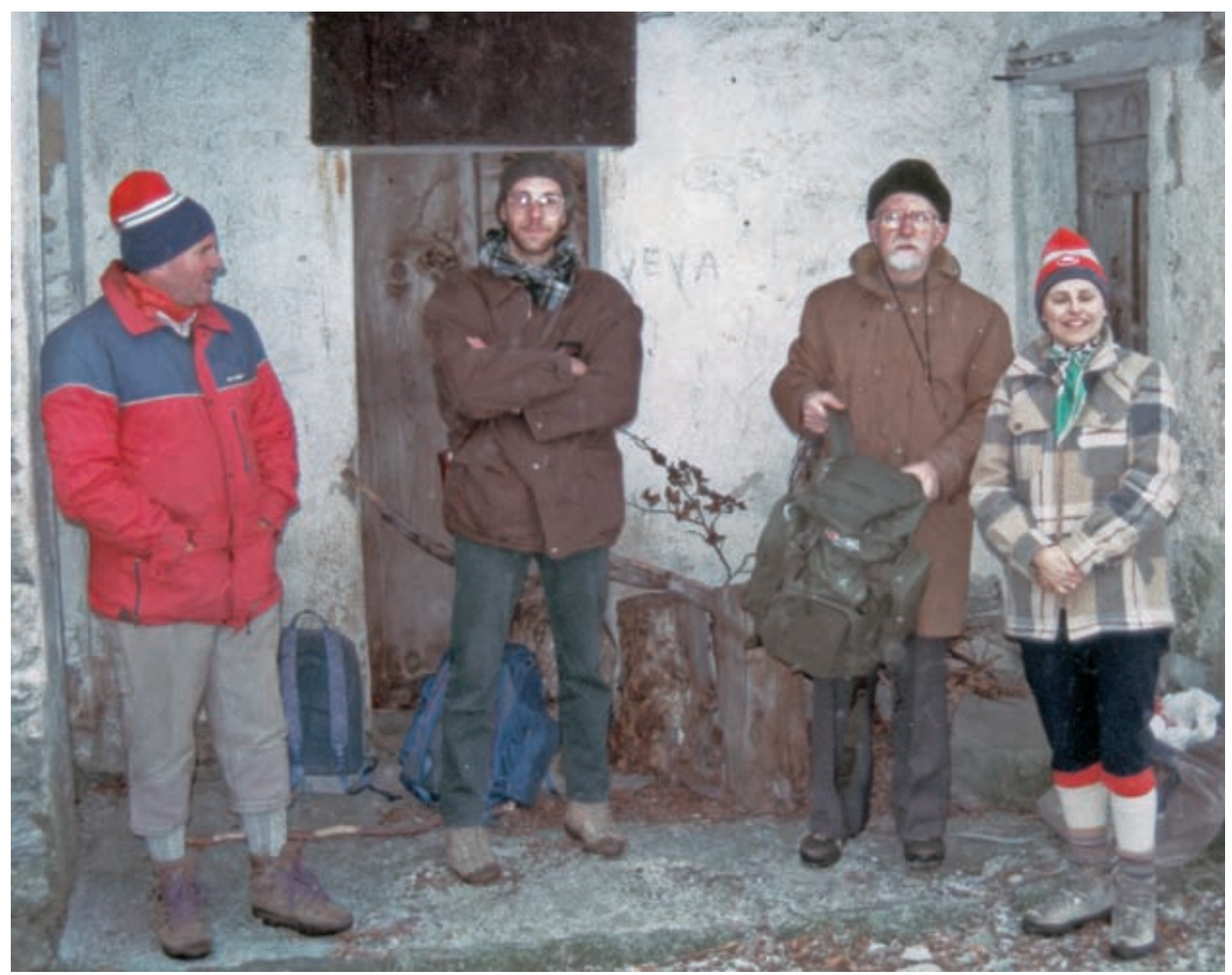

Fig. 1 - A moment of the fieldwork in Luinese. From the left: Gianni Schiroli, Andrea Viganò, Luigi Cagnolaro e Laura Rinetti. (Photo by Carlo Biancardi). 


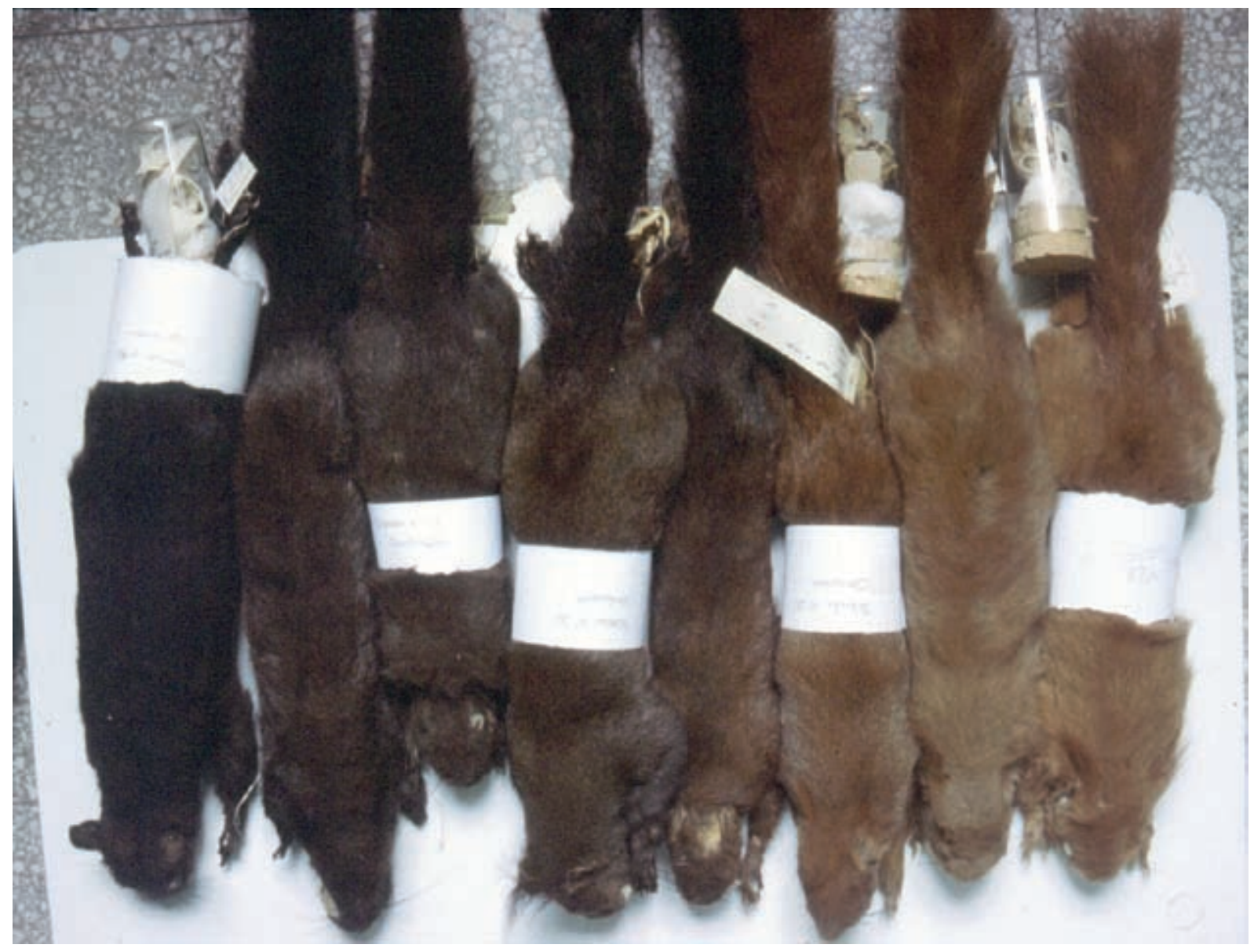

Fig. 2 - Fur colour polymorphism in Sciurus vulgaris. Collection of the Museum of Natural History of Milan MSNM. (Photo by Carlo Biancardi).

Questionnaires $(\mathrm{n}=132)$, prepared by the authors and distributed at the end of 1991, were filled by members of the Corpo Forestale dello Stato (CFS, Forest Rangers) of Lombardy (Northern Italy). They included 8 questions, concerning the general presence and abundance of the species and data from punctual observations with i) the colour phase: dark or red; ii) the altitude and iii) the environment. The latter part of the questionnaire, concerning the observation of individuals, was used to collect information from Guardie Ecologiche Volontarie (GEV, Ecological Guards) and from the students during their surveys.

\section{Population ecology}

The field researches were carried out in five study areas, characterised by different kind of woods (Fig. 3; Tab. 1 ). Here, the population densities of red squirrels were estimated using two indirect methods (Sutherland, 2006; Gurnell et al., 2009):

i) the feeding sign survey by quadrat sampling of $5 \times 5 \mathrm{~m}$.

ii) the drey counts by quadrat sampling of 1 ha $(100 \times 100 \mathrm{~m})$ or on line transects. The number of hectares and the length of the linear transects are reported in Tab. 1.

\section{Feeding sign survey}

This technique is applicable in coniferous woods, where the cones eaten by squirrels remain on the ground and are easily detected and identified (e.g. Bang et al., 2001). The study area was divided in quadrats of $5 \times 5 \mathrm{~m}$, and the sampling quadrats were chosen using a random

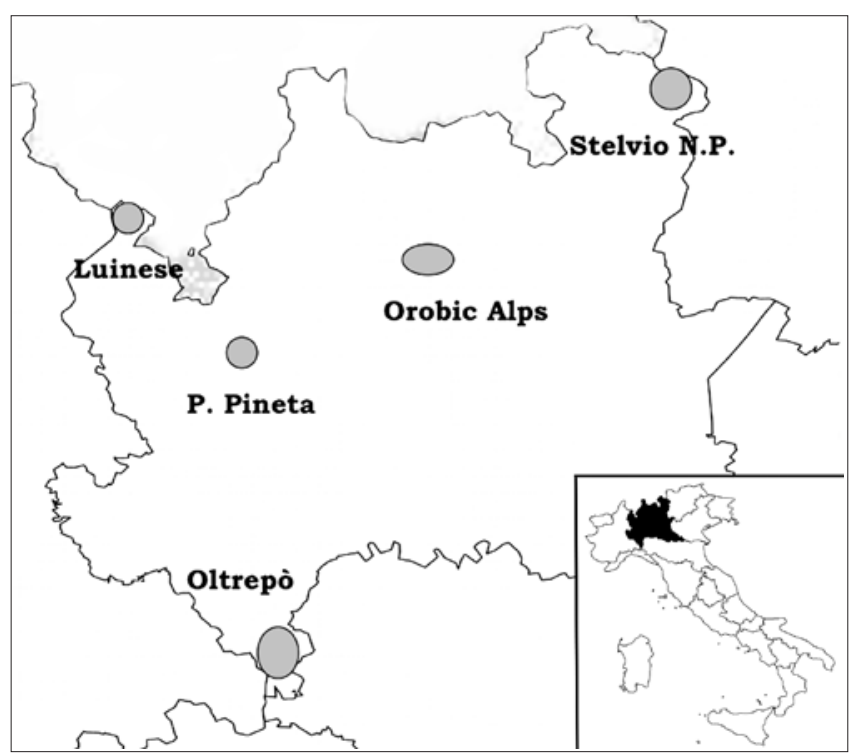

Fig. 3 - Study areas in Lombardy. Box: geographic position of Lombardy (black) in Italy. 
Tab. 1 - Study areas, forest composition, main tree species and census methods employed.

\begin{tabular}{|l|l|l|l|c|c|c|}
\hline Author & Study area & Macro-area & Forest composition & $\begin{array}{c}\text { Feeding } \\
\text { remains } \\
\text { (cones) }\end{array}$ & $\begin{array}{c}\text { Dreys: } \\
\text { quadrat } \\
\text { sampling } \\
\text { (Ha) }\end{array}$ & $\begin{array}{c}\text { Dreys: } \\
\text { transect } \\
\text { sampling } \\
\text { (km) }\end{array}$ \\
\hline $\begin{array}{l}\text { Speranza, } \\
1992\end{array}$ & $\begin{array}{l}\text { Piazzatorre } \\
\text { (BG) }\end{array}$ & Orobic Alps & Conifers (Spruce, Silver fir) & 11 & \\
\hline $\begin{array}{l}\text { Speranza, } \\
1992\end{array}$ & $\begin{array}{l}\text { San Lucio } \\
\text { (BG) }\end{array}$ & Orobic Alps & Conifers (Spruce) & & 12 & \\
\hline $\begin{array}{l}\text { Aristarchi, } \\
1996\end{array}$ & Uzza (SO) & Stelvio N.P. & Conifers (Larch) & & 50 & \\
\hline $\begin{array}{l}\text { Dell'Acqua, } \\
1998\end{array}$ & $\begin{array}{l}\text { Appiano } \\
\text { Gentile (CO), } \\
\text { Tradate (VA) }\end{array}$ & Parco Pineta & $\begin{array}{l}\text { Conifers and Broadleaved (Scots } \\
\text { pine, Oaks) }\end{array}$ & X & & 26 \\
\hline $\begin{array}{l}\text { Viganò, } \\
1998\end{array}$ & Luinese (VA) & Prealps & $\begin{array}{l}\text { Mixed Broadleaved (Oaks, Beech, } \\
\text { Chestnut) }\end{array}$ & & & 24 \\
\hline $\begin{array}{l}\text { Aquilini, } \\
2000\end{array}$ & $\begin{array}{l}\text { Valle Staffora } \\
\text { (PV) }\end{array}$ & Oltrepò & Broadleaved (Oaks) & & & 19 \\
\hline
\end{tabular}

integer generator. During the delimitation of the sampling quadrats (first visit, t0), all the cones were removed. Thereafter, at periodic intervals $(\mathrm{t} 1, \mathrm{t} 2, \ldots)$, the new cones were collected and removed from the sampling area. In this way, the estimated number of cones eaten by squirrels per unit area and per day can be calculated. The average number of cones eaten per day by one red squirrel can be estimated from: i) the energetic requirement of the species: an adult red squirrel was supposed to need between 330 and $420 \mathrm{~kJ} /$ day (Grönwall, 1982), but more recent data set this energy requirement between 400 and $700 \mathrm{~kJ}$ per day (Gurnell et al., 2009); ii) the amount of energy of an unit mass of seeds $(\mathrm{kJ} / \mathrm{g})$; the average number of seeds, or their weight, per cone.

\section{Drey counts}

The density of red squirrel dreys is a proxy of the population density of the species (Wauters \& Dhondt, 1988; 1990). Contrary to what is commonly thought, red squirrels infrequently build their nest in holes in trees, called dens, but more commonly they built nesting structures, called dreys, in the tree canopy. Dreys are sub-spheric structures of $30-50 \mathrm{~cm}$, made by twigs and leaves, usually built close to the trunk or one of the main branch of a tree (Biancardi \& Do Linh San, 2006). A red squirrel can build and maintain a variable number of dreys within its territory, usually between 4 and 6 (Wauters \& Dhondt, 1990). Dreys can be more easily detected in broadleaved woodlands in winter, when the leaves are gone (Gurnell et al., 2009). The same happens in larch woods (Aristarchi, 1996). In other conifer woods the count, either on quadrats or on line transects, takes more time and the possibility of underestimate the real number of dreys is higher.

The study area was divided in quadrats of $100 \times 100 \mathrm{~m}$ and, like for feeding sign survey, the sampling quadrats were chosen using a random integer generator.

The following additional data were collected during the surveys: position of the drey (close to the trunk or dif- ferent), orientation, height, tree species and tree diameter (at $1.5 \mathrm{~m}$ from the ground).

\section{Statistical analysis}

The differences in colour phase ratio and the distributions of observed against expected frequencies were tested using Chi-squared or G-test of goodness-of-fit (Sokal \& Rohlf, 2003). The orientation of squirrel dreys on the tree trunks was analysed applying the Rayleigh $z$-test, with the null hypothesis $\left(\mathrm{H}_{0}\right)$ that there is no preferred direction (Batschelet, 1981).

\section{RESULTS}

\section{Presence and colour phases}

The feedback from CFS stations was geographically inhomogeneous: half of the information came from the district of Brescia (BS), one third from the districts of Bergamo $(\mathrm{BG})$ and Sondrio $(\mathrm{SO})$, and the rest $(<20 \%)$ from the districts of Como (CO), which included the current territory of Lecco, Varese (VA), Pavia (PV) and Milano (MI), which included the current territory of MonzaBrianza. The Centro Studi did not get reply from the districts of Mantova (MN) and Cremona (CR).

A total of 1346 observations of red squirrels were recorded, and the ratio between the dark and red colour phases (CPR) resulted 2:1. The CPR significantly changed in favour of the dark phase while ascending in elevation $(\mathrm{G}=48.56, \mathrm{df}=5, \mathrm{P}<0.01)$ (Fig. 4). Slight differences of CPR in favour of the dark phase occurred as well in all the conifer woodlands, while an opposite trend was observed in broadleaved woodlands (regardless of the altitude).

\section{Feeding sign survey}

The feeding sign surveys were carried out in two study areas (Tab. 1). In one case the sampling quadrats were built in a scots pines wood, in the second area the 


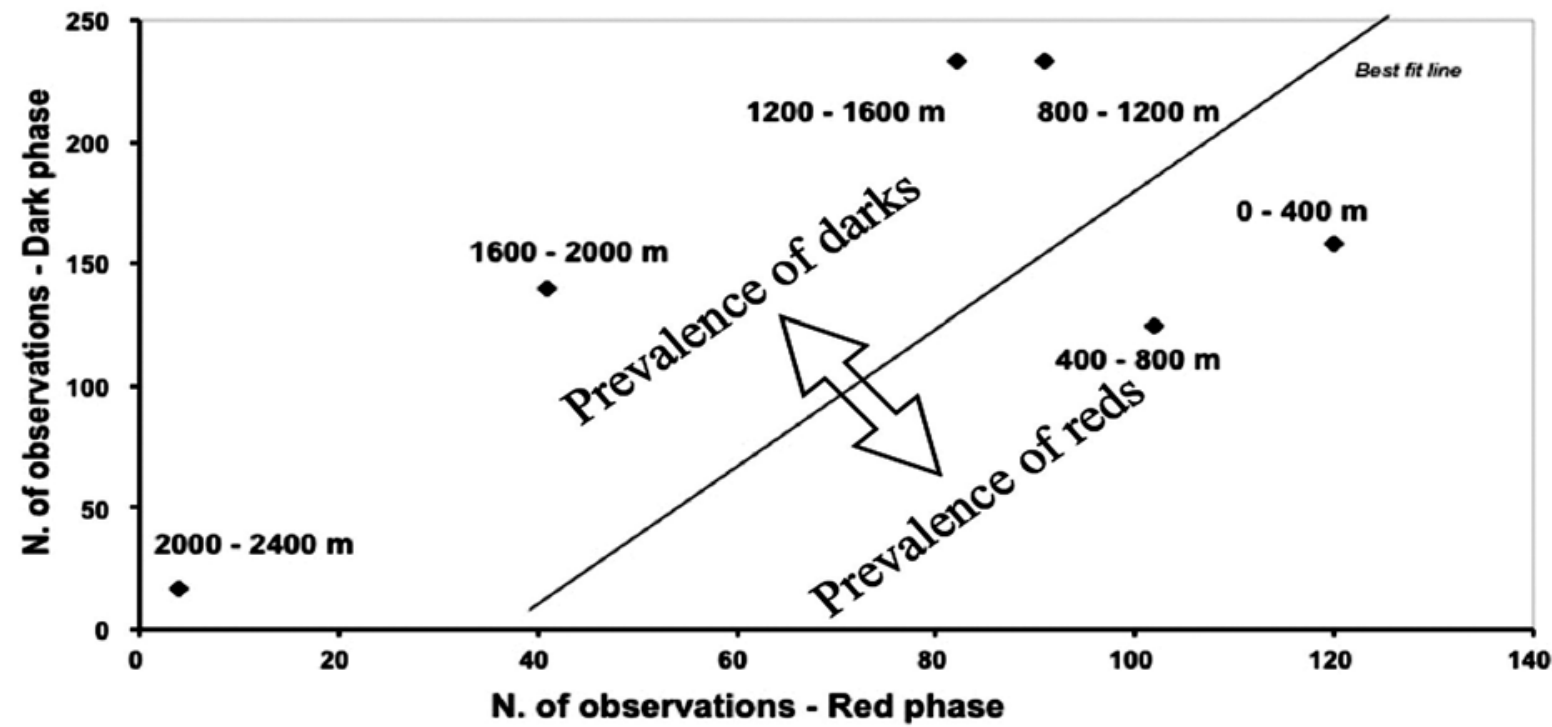

Fig. 4 - Observations of red and dark phases per altitudinal range. The dark phase became prevalent, with respect to the mean colour phase ratio, above $800 \mathrm{~m}$ a.s.l.

dominant species was the Austrian pine (Pinus nigra). The estimated numbers of scots pine cones eaten by one red squirrel per day was taken from literature: Purroy \& Rey (1974) estimated this number being between 114 and 143. The energy content of Austrian pine seed is $15.5 \mathrm{~kJ} / \mathrm{g}$ (Grodzinski \& Sawicka-Kapusta, 1970). Aquilini (2000) calculated the average weight of the seeds contained in one cone: $0.34 \pm 0.3 \mathrm{~g} / \mathrm{cone}$. The estimated number of Austrian pine cones eaten per day (62-80) was based on the energetic requirements data in Grönwall (1982). The new estimation, based on a requirement of 400-700 kJ/day (Gurnell et al., 2009), set this number in the range of 83-146 cones per days per squirrel. The estimated densities of population from feeding sign survey are reported in Tab. 2.

\section{Drey counts}

A total number of 1179 dreys were counted during the whole period in all the study areas (Tab. 3). Southern exposures (South-Southeast-South-Southwest) were generally preferred (Rayleigh z-test; $\mathrm{P}<0.05$ in all areas; $\mathrm{P}<0.001$ on the total mean), but in mountain areas the results can be influenced by the slope exposure (Fig. 5). The dreys resulted mainly built between the trunk and one main branch (Chi-square: $\mathrm{P}<0.001)$, and in the higher part of the canopy: the ratio between the height of the nest and of the tree was $0.816 \pm 0.117$. Two abandoned dreys, in Uzza and Luinese, have been found fallen on the ground, collected and analysed (Tab. 4).

The drey densities, together with an estimation of the red squirrel population density, as found in quadrat sampling and in linear transect counts are reported in Tab. 5.

During their survey, Aristarchi \& Canu (1999) collected 208 mushrooms stored by squirrels on trees.
Tab. 2 - Average density of population estimated from feeding sign surveys.

${ }^{1}$ According to the average number of cones eaten per day (Purroy \& Rey, 1974); ${ }^{2}$ According to the energy values in Gurnell et al. (2009).

\begin{tabular}{|c|c|c|}
\hline Study area & Years & Average squirrels/Ha \\
\hline Parco Pineta $^{1}$ & $1995-97$ & $1.4-1.8$ \\
\hline Monte Alpe $^{2}$ & $1998-99$ & 0.40 .7 \\
\hline
\end{tabular}

Tab. 3 - Overall number of dreys.

\begin{tabular}{|l|c|}
\hline \multicolumn{1}{|c|}{ Type of wood } & N. of dreys \\
\hline Mixed broadleaved & 265 \\
\hline Larch woods & 252 \\
\hline Mixed broadleaf + conifers & 245 \\
\hline Chestnut woods & 171 \\
\hline Chestnut + other broadleaf & 130 \\
\hline Mixed conifers & 89 \\
\hline Ash and alder & 5 \\
\hline Black locust & 8 \\
\hline Beech woods & 7 \\
\hline Shrubs & 3 \\
\hline Moor with trees & 2 \\
\hline Downy oak woods & 1 \\
\hline Isolated tree & 1 \\
\hline
\end{tabular}




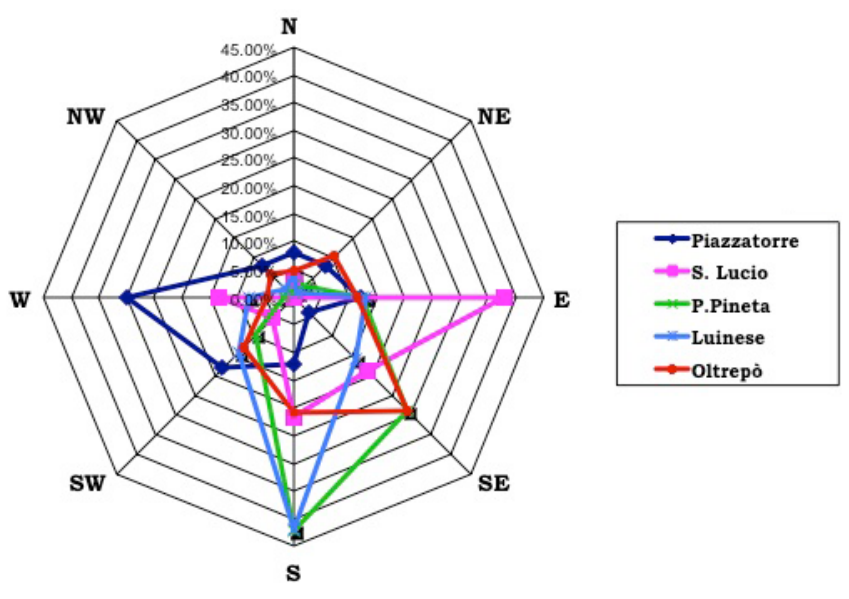

Fig. 5 - Orientation of the red squirrel dreys per study area.

Tab. 4 - Analysis of two fallen dreys

\begin{tabular}{|l|l|l|}
\hline Analysis of a drey & Stelvio & Luinese \\
\hline Drey measures & $\begin{array}{l}32 \times 30 \times \\
12 \mathrm{~cm}\end{array}$ & $\begin{array}{l}40 \times 19 \times \\
13 \mathrm{~cm}\end{array}$ \\
\hline Total weight & $666 \mathrm{~g}$ & $210 \mathrm{~g}$ \\
\hline Frame weight & $334 \mathrm{~g}$ & $100 \mathrm{~g}$ \\
\hline Stuffing weight & $332 \mathrm{~g}$ & $110 \mathrm{~g}$ \\
\hline N. of twigs & & 64 \\
\hline Max. diameter of the twigs & & $5 \mathrm{~mm}$ \\
\hline Lenght of the twigs & & $10-40 \mathrm{~cm}$ \\
\hline Ramifications of the twigs & & $0-4$ \\
\hline
\end{tabular}

\section{DISCUSSION}

This review covers a time span of about ten years, till the beginning of the 2000s. Some information are of course out-dated, i.e. the estimations of population densities, but could be used as historical reference of the status of the red squirrel populations at that time in these areas.

There is an old debate about the adaptive meaning of the coat colour polymorphism in some sub-species of Sciurus vulgaris, like the S.v. fuscoater. In particular Voipio (1970) claimed the role of the mean temperatures on the colour polymorphism. According to Voipio \& Hissa (1970) the melanic individuals would have thicker furs and longer hairs with respect to brown and reddish. The greater insulating power of melanic furs would favour a better thermoregulation in cold environments. The same idea was suggested by Hancock \& Nash (1979, in Gurnell, 1987), for Sciurus alberti. The significant relationship between dark colour phase and higher altitudes in mountains found during the researches of the "Sciurus group" is in agreement with the thermoregulation theory. More recently, a huge work involving 9 study areas has been carried out by Wauters et al. (2004), considering the three colour phases red, brown and black. According to the authors, better thermoregulation and more cryptic coat would give an advantage to melanic individuals in cold and dense spruce-fir forests of the Alps. Concealment has also been recently indicated as the factor more strongly related to the coat colour of Sciuromorpha (Ancillotto \& Mori, 2016). However, a differential survival rate of the morphotypes, associated to temperature/elevation or predation has not been demonstrated (Wauters et al., 2004).

The feeding sign survey in conifer woodlands is one of the monitoring strategies that can be used when only one species of squirrels is likely to be present (Gurnell

Tab. 5 - Estimated dreys and red squirrel densities. Pre-br) average pre-breeding density; Year) average of the whole year. *) estimation based on mean values of 4.85 dreys/squirrel in broadleaved woodlands and 5.17 dreys per squirrel in conifer woodlands (Wauters \& Dhondt, 1990).

\begin{tabular}{|l|c|c|c|}
\hline Study area & Method & Dreys/Ha (min-max) & Sq/Ha* \\
\hline P. Pineta & Line transects & 2.1 (year) & 0.4 \\
\hline Luinese '94 & Line transects & 1.0 (pre br.) & 0.2 \\
\hline Luinese '95 & Line transects & 1.0 (pre br.) & 0.2 \\
\hline Luinese '97 & Line transects & 0.4 (pre br.) & 0.1 \\
\hline Val Staffora & Line transects & 0.8 (pre br.) & 0.2 \\
\hline S. Lucio & Quadrat sampling & 3.4 (year) & 0.7 \\
\hline Piazzatorre & Quadrat sampling & $4.1(3.1-4.7)$ & $0.8(0.6-0.9)$ \\
\hline Uzza ('93) & Quadrat sampling & 4.5 (pre-br.) & 0.9 \\
\hline Uzza ('94) & Quadrat sampling & 5.0 (pre br.) & 1.0 \\
\hline M.te Alpe & Quadrat sampling & $1.8(1.7-2.0)$ & $0.3(0.3-0.4)$ \\
\hline
\end{tabular}


et al., 2009). Indeed, at the time of this cycle of studies, introductions of grey squirrels in Lombardy were not known (Martinoli et al., 2010). The power of this method to estimate population densities is moderate, however better than drey counts (poor-moderate) and better than others indirect methods, out of visual survey (Gurnell et al., 2009). One of the critical points of the estimation is that there are different approximations: the mean number of seed per cone, the mean energy of a cone, assuming that a high percentage or all the seeds are eaten, the energy requirement of an individual. There is also the possibility that squirrels are taking advantage of other feeding sources, like mushrooms, which can be available in conifer woodlands as well (Lurz \& South, 1998; Aristarchi \& Canu, 1999). The densities estimated with this method can dramatically change according to the annual cone crop, but this reflects the real fluctuations of population density related to food availability (Gurnell et al., 2004).

The results of drey counts have been obtained using the average number of dreys per squirrel as reported in Wauters \& Dhondt $(1988 ; 1990)$. To our knowledge, those are the most recent and still used available estimations (Gurnell et al., 2004; 2009).

Drey counts, like feeding sign survey, cannot discriminate between red and grey squirrels (Gurnell, 2004). This is one of the reasons why this monitoring method has fallen into abeyance in Italy, and replaced by hairtube surveys (Bertolino et al., 2009). More recently, also camera trapping has been proved to be an efficient method for assessing the presence and monitoring the populations of arboreal small mammals (Di Cerbo \& Biancardi, 2013).

The ecological characteristics of the dreys exposed in results are in line with other published data (e.g. Fornasari et al., 1997). Red squirrels prefer to build their nests in a sheltered and protected position, near the main trunk and in the medium-higher part of the canopy, but with an orientation that can favour a better insolation.

In conclusion, the cycle of researches promoted by Luigi Cagnolaro in the nineties can still represent a historical point of reference to understand and deal with a situation that, with the senseless introductions of the grey squirrel in Lombardy, has dramatically changed. The investigated areas, being still out or partially interested by the presence of the grey squirrel, can be part of a pool of red squirrel populations suitable for a natural expansion after a desirable eradication of the alien species.

\section{Acknowledgements}

These works could never have been carried out without the unceasing contribution and the passionate support of Luigi Cagnolaro (1934-2014). His scientific legacy, his subtle sense of humor and his friendship will always remain with us.

Many thanks to the students, researchers and friends who participate to the field, museum and paper works: Lorena Aquilini, Claudio Aristarchi, Giorgio Bardelli, Paola Cambiaghi, Guido Canu, Franco Dell'Acqua, Anna Rita Di Cerbo, Tiziana Gambacorta, Gianni Schiroli, Alessandra Speranza, Andrea Viganó. We would like to thanks in particular Laura Rinetti, for her great contribution to the group, during the fieldwork in Luinese, as cotutor and as friend. Further we thanks: the coordinator of Centro Studi "Arvicola" of the Società Italiana di Scienze Naturali (1992-1995), Barbara Chiarenzi; the curators of mammals of the Museum of Natural History of Milan: Giorgio Chiozzi and Michela Podestà; Luc Wauters, for his support and suggestions; the Guardie Ecologiche Volontarie (GEV) and the responsible of the local sections of Corpo Forestale dello Stato (CFS), who collaborated to the survey. Finally, thanks to the two anonymous reviewers, which helped to improve the paper.

\section{REFERENCES}

Ancillotto L. \& Mori E., 2016 - Adaptive significance of coat colouration and patterns of Sciuromorpha (Rodentia). Ethology Ecology \& Evolution, 1-14. doi: 10.1080/03949370.2016.1145146

Andera M., 1985 - Geographical distribution of the colour phases of the red squirrel in Bohemia and Moravia (Mammalia: Sciuridae). Vestnik Ceskoslovenske Spolecnosti Zoologicke, 49 (1): 1-5.

Aquilini L., 2000 - Studio della densità di popolazione dello Scoiattolo rosso (Sciurus vulgaris) in Oltrepò pavese. Unpublished Master Thesis, Università degli Studi di Milano.

Aristarchi C., 1996 - Studio di una popolazione di scoiattolo (Sciurus vulgaris Linnaeus, 1758) e dell'utilizzo dei funghi come riserva alimentare nel Vallone di Uzza (Parco Nazionale dello Stelvio). Università degli Studi di Genova.

Aristarchi C. \& Canu G., 1999 - I funghi come riserva alimentare dello scoiattolo (Sciurus vulgaris linnaeus, 1758) nel Parco Nazionale dello Stelvio. Atti della Società Italiana di Scienze Naturali e del Museo Civico di Storia Naturale di Milano, 140 (1): 23-29.

Bang P., Dahlstrøm P. \& Walters M., 2001 - Animal tracks and signs. Oxford University Press, Oxford.

Batschelet E., 1981 - Circular statistics in biology. Academic Press, London.

Bertolino S., di Montezemolo N.C., Preatoni D.G., Wauters L.A. \& Martinoli A., 2014 - A grey future for Europe: Sciurus carolinensis is replacing native red squirrels in Italy. Biological invasions, 16 (1): 53-62. doi:10.1007/s10530-013-0502-3.

Bertolino S., Wauters L., Pizzul A., Molinari A., Lurz P. \& Tosi G., 2009 - A general approach of using hair-tubes to monitor the European red squirrel: a method applicable at regional and national scales. Mammalian Biology, 74 (3): 210-219. doi: 10.1016/j. mambio.2009.02.003

Biancardi C.M., 1998a - Distribuzione delle fasi di colore nello Scoiattolo (Sciurus vulgaris L., 1758) in Lombardia. $2^{\circ}$ Congresso Italiano di Teriologia - Varese 28-30 October 1998.

Biancardi C.M., 1998b - Indagine sulla presenza dello Scoiattolo (Sciurus vulgaris L., 1758) in Lombardia in relazione alle fasi di colore. $2^{\circ}$ Congresso Italiano $d i$ Teriologia, Varese 28-30 October 1998. 
Biancardi C.M., 1999 - Dati preliminari sulla frequenza delle due fasi cromatiche dello Scoiattolo (Sciurus vulgaris L., 1758) nelle province di Como, Lecco e Sondrio (Lombardia, Italia). Atti del Museo Civico di Ornitologia e Scienze Naturali di Varenna, 4: 1623.

Biancardi C.M. \& Do Linh San E., 2006 - L'écureuil roux. Bélin - Evéil Nature, Paris.

Biancardi C.M. \& Gnoli C., 2001 - Red squirrels (Sciurus vulgaris) in Lombardy: a review of the Sciurus Group studies. 6th Squirrel Workshop, Acqui Terme 11-13 September 2001.

Biancardi C.M., Gnoli C., Rinetti L., Aristarchi C., Dell'acqua F., Speranza A., Aquilini L., Canu G. \& Viganò A., 1998 - Densità di popolazione dello Scoiattolo (Sciurus vulgaris L., 1758) in alcune aree della Lombardia. $2^{\circ}$ Congresso Italiano di Teriologia, Varese 28-30 October 1998.

Celada C., Bogliani G., Gariboldi A. \& Maracci A., 1994 - Occupancy of isolated woodlots by the red squirrel Sciurus vulgaris L. in Italy. Biological Conservation, 69: 177-183. doi: 10.1016/0006-3207(94)90057-4.

Dell'Acqua F., 1998 - Studio di una popolazione di Scoiattolo (Sciurus vulgaris L., 1758) nel Parco Regionale della Pineta di Appiano Gentile e Tradate, con stima della densità di popolazione. Università degli Studi di Milano.

Di Cerbo A.R. \& Biancardi C.M., 2013 - Monitoring small and arboreal mammals by camera traps: effectiveness and applications. Acta Theriologica, 58 (3): 279-283. doi: 10.1007/s13364-012-0122-9

Dickinson J.L., Zuckerberg B. \& Bonter D.N. 2010 - Citizen science as an ecological research tool: challenges and benefits. Annual review of ecology, evolution, and systematics, 41: 149-172.

Fornasari L., Casale P. \& Wauters L., 1997 - Red squirrel conservation: the assessment of a reintroduction experiment. Italian Journal of Zoology, 64 (2): 163-167. doi: 10.1080/11250009709356190.

Grodzinski W. \& Sawicka-Kapusta K., 1970 - Energy values of tree-seeds eaten by small mammals. Oikos, 21: 52-58. doi: 10.2307/3543838.

Grönwall O., 1982 - Aspects of the food ecology of the red squirrel (Sciurus vulgaris L.). University of Stockholm.

Gurnell J., 1987 - The Natural History of Squirrels. $C$. Helm, London.

Gurnell J., Lurz P., McDonald R. \& Pepper H., 2009 Practical techniques for surveying and monitoring squirrels. Forestry Commission Practice Note, 011.

Gurnell J., Lurz P. W.W., Shirley M.D.F., Cartmel S., Garson P.J., Magris L. \& Steele J., 2004 - Monitoring red squirrels Sciurus vulgaris and grey squirrels Sciurus carolinensis in Britain. Mammal Review, 34 (1, 2): 51-74. doi: 10.1046/j.0305-1838 .2003.00028.x

Lurz P.W.W. \& South A.B., 1998 - Cached fungi in nonnative conifer forest and their importance for red squirrels (Sciurus vulgaris L.). Journal of Zoology, London, 246: 468-471.
Martinoli A., Bertolino S., Preatoni D.G., Balduzzi A., Marsan A., Genovesi P. \& Wauters L.A., 2010 Headcount 2010: the multiplication of the grey squirrel populations introduced to Italy. Hystrix, the Italian Journal of Mammalogy, 21 (2): 127-136. doi: 10.4404/ hystrix-21.2-4463

Mori E. \& Menchetti M., 2014 - Sometimes they come back: citizen science reveals the presence of the Italian red squirrel in Campania. Quaderni del Museo Civico di Storia Naturale di Ferrara, 2: 91-94.

Purroy F.J. \& Rey J.M., 1974 - Estudio ecologico y sistematico de la ardilla (Sciurus vulgaris) en Navarra. 1. Distribucion, densidad de poblaciones, alimentacion. Actividad diaria y anual. Boletin Estacion Central Ecologia, 3 (5): 71-82.

Sokal R.S. \& Rohlf F.J., 2003 - Biometry. 3rd Edition. W.H. Freeman, New York.

Speranza A., 1992 - Studio di due popolazioni di Scoiattolo (Sciurus vulgaris L.1758) nelle valli Brembana e Seriana e valutazione della distribuzione della specie nella provincia di Bergamo. Università degli Studi di Milano.

Sutherland W.J. (ed.)., 2006 - Ecological census techniques: a handbook. Cambridge University Press, Cambridge.

Viganò A., 1998 - Lo Scoiattolo (Sciurus vulgaris L., 1758) nel territorio della Comunità Montana Valli del Luinese (VA): distribuzione, posizionamento del nido e fasi di colore. Università degli Studi di Milano.

Voipio P., 1970 - Polymorphism and regional differentiation in the red squirrel (Sciurus vulgaris L.). Annales Zoologici Fennici, 7: 210-215.

Voipio P. \& Hissa R., 1970 - Correlation with fur density of color polymorphism in Sciurus vulgaris. Journal of Mammalogy, 51: 185-187. doi: 10.2307/1378560.

Wauters L.A. \& Dhondt A.A., 1988 - The use of red squirrel (Sciurus vulgaris) dreys to estimate population density. Journal of Zoology, London, 214: 179187. doi: 10.1111/j.1469-7998.1988.tb04995.x

Wauters L.A. \& DhondtA.A., 1990-Nest-use by red squirrels (Sciurus vulgaris Linnaeus, 1758). Mammalia, 54 (3): 377-389. doi: 10.1515/mamm.1990.54.3.377.

Wauters L.A., Zaninetti M., Tosi G. \& Bertolino S., 2004 Is coat-colour polymorphism in Eurasian red squirrels (Sciurus vulgaris L.) adaptive? Mammalia mamm, 68 (1): 37-48. doi:10.1515/mamm.2004.005

Zawidzka E., 1958 - Geographical distribution of the dark phase of the squirrel (Sciurus vulgaris fuscoater Altum) in Poland. Acta Theriologica, 2: 159-174. 